\title{
U.S. NAVY BATTERY REQUIREMENTS AND DEVELOPMENT EFFORTS
}

\author{
Patricia H. Smith, Stanley D. James and Peter B. Keller \\ Naval Surface Warfare Center \\ Carderock Division \\ Silver Spring, Maryland 20903-5640
}

\begin{abstract}
Under the sponsorship of the Office of Naval Research, the Naval Surface Warfare Center (NSWC) is the focal point for exploratory battery development within the United States Navy. NSWC is responsible for identifying naval power needs not met by existing technology. To accomplish this, we conduct a biennial power source survey to assess the technology gap between state-of-the-art battery performance and mid-to-long term fleet needs. Once Navy power requirements have been identified, high payoff technologies are developed to meet them.

During the 1993 survey, we identified four Navy systems requiring battery developments, namely sonobuoys, mines, underwater vehicles and torpedoes. Power supply inadequacies were found to be the result of two important factors, a shift in Navy focus from deep ocean waters to the more complex, littoral (coastal) environments, and an increased emphasis on the cost effectiveness of a system in an era of reduced military budgets. The survey revealed the following issues: (1) Future sonobuoys will require significantly greater power than the presently used lithium/sulfur dioxide batteries can provide. (2) There is concern in the mine community over the future availability of specific batteries. (3) In the case of underwater vehicles (including torpedo targets), there is a desire for a more cost-effective power source having a greater energy density than the presently used silver oxide/zinc cells. (4) Enhanced energy density was requested by the torpedo community to provide increased operational time. As expected, safety and environmental issues were of concern to participants responding to the survey. This paper will discuss the recommendations of the power needs survey and summarize efforts underway to implement them.
\end{abstract}

US Government work not protected by US copyright

\section{Introduction}

Virtually every modern naval weapons system, in fulfilling its mission, is highly dependent upon the performance characteristics of its electrochemical power supply. For example, batteries are used to power detection, guidance, control, ignition, propulsion, arming, fuzing, transmitting and jamming devices. During the past twenty years, the need for weapons with increased range, speed, endurance, sensitivity and accuracy created battery requirements which could not be fulfilled with conventional technology. In many instances, batteries have become the limiting factor in improving the performance of weapon systems. As a result, the Office of Naval Research tasked the Carderock Division of the Naval Surface Warfare Center (NSWC) to identify those naval power needs that are not being met by existing technology, to keep abreast of electrochemical advances taking place in government, industrial and academic laboratories, and where suitable matches exists, use them to solve specific Navy problems. Solving these problems, however, typically requires a collaborative effort with an industrial partner who has the necessary experience and facilities. This process, called Exploratory Battery Development, ranges from applied research to development of sophisticated military breadboard hardware which can result in technological spin-offs for consumer applications.

Every other year, NSWC sends out a Power Source Needs Survey Form to Program Managers at the various Navy Laboratories and Command Centers to identify battery deficiencies in existing or future naval systems. It requests a detailed description of the electrical, physical and environmental requirements of system power supplies that the user believes can not be provided 
by off-the-shelf technology. Responses are reviewed and the respondents are informed of any existing technology that meets their needs. If an area requiring power source capabilities beyond the stateof-the-art is identified, it is considered as a candidate for technology development. Our last survey, completed in FY93, revealed that now, more than ever, future naval systems will require affordable batteries which are environmentally friendly and have even greater energy and power density.

\section{Future Battery Requirements}

The demise of the Soviet Union means that we will not, in the foreseeable future, be involved in a large-scale struggle for national survival. The major threat to global peace appears to be Third World countries engaged in regional conflict. Today two of the most difficult tactical challenges for the U.S. Fleet are submerged, ultra quiet, diesel-electric submarines hugging the coastline, and mines laid in coastal water. To respond to these new threats, the Navy must invest in new technologies while ensuring that the resultant weapon system is still affordable in an era of increased domestic economic pressures. The following are specific examples of technology shortfalls identified by our Power Needs Survey and the development efforts underway to prepare the US Navy for these future challenges.

\section{Sonobuoys}

For decades, the Navy's primary means of detecting and tracking submarines in deep ocean waters has been passive sonar which uses hydrophones to pick up the characteristic sounds emitted by the submarine's engine, propeller and other sources. Passive sonar was preferred since it did not emit signals that could reveal the searcher's location. With the advent of quieter submarines however, the Navy began shifting its antisubmarine warfare emphasis from passive listening devices to signal emitting or active sensors. Today, as the likelihood of regional conflict increases, the U.S. Navy must be prepared to detect quiet submarines in highly cluttered, shallow coastal waters. Such environments are noisy, making submarine detection very difficult. To complicate matters, sounds emitted for detection are prone to distortion by rocky continental shelves. Fortunately the situation may be ameliorated by using low frequency sound waves which are less subject to problems of reverberation.

Active sonobuoys project trains of sound waves ("pings") into the water and then receive echoes reflected from solid objects. Greater sonar range capability and a longer sonobuoy life would offer the Navy significantly improved operational effectiveness. Increased range can be achieved with greater battery energy and power density. The latest active sonobuoy, DICASS AN/SSQ-62C, soon to be released to the fleet, still uses the higher frequencies. Its battery must provide 75 pulse seconds at 600 watts over a one hour mission time (energy density of $10.66 \mathrm{Wh} / \mathrm{kg}, 20 \mathrm{Wh} / \mathrm{l})$. Low frequency active sonobuoys are being developed at the Naval Air Warfare Center (NAWC), Warminster, PA. The new Air Deployable Low Frequency Projector Sonobuoy being developed by NAWC requires 4.2 kilowatts with an energy density of 35-40 Wh/kg (60-80 Wh/l) over a 4 hour period. Present sonobuoys use linear amplifiers. However, future sonobuoy designs may use switching amplifiers which would place even greater demands on the power supply. Under these circumstances, the battery would have to be capable of delivering pulses (10 microsecond pulse width) at very high frequencies (e.g, $50 \mathrm{kHz}, 50 \%$ duty cycle) and have a rise time no greater than 5 microseconds. Efforts are now underway to determine the feasibility of this scenario. In particular, investigations must be conducted to determine whether candidate electrochemistries can deliver power with such short rise times.

Prior development of battery pulse power for sonobuoys have been conducted by Yardney Technical Products and SAFT Research and Development Center. Yardney, located in Pawcatuck, CT, concentrated on a lithium/thionyl chloride bipolar battery configuration in order to achieve twenty, 20-second, $10.7 \mathrm{~kW}$ pulses. ${ }^{1}$ A 150-cell (three, 50-cell stacks connected in series) battery was fabricated and pulse tested (20-second pulse, $10 \%$ duty cycle) at constant power. Problems 
plagued the building and testing of these batteries. The stack sealing, cell activation, and the handling of large modules during assembly presented the biggest problems. The battery delivered 19 pulses, some of which, however, were less than 20-second duration. The total pulse time delivered from the battery was equivalent to only fourteen of the desired twenty, 20-second pulses.

SAFT, located in Cockeysville, MD, had a more successful program. Their goal was the development of a $4.2 \mathrm{~kW}$ short life thermal battery ${ }^{2}$ (20-second lifetime delivering one 10-second pulse) and a $4.2 \mathrm{~kW}$ long life thermal battery (1 hour lifetime delivering ten, 10-second pulses). This program was very successful. The batteries employed the $\mathrm{Li} / \mathrm{FeS}_{2}$ electrochemical system with a ternary lithium halide electrolyte. The short life battery delivered extremely high power densities of $8,750 \mathrm{~W} / \mathrm{Kg}$ and $101 \mathrm{~W} / \mathrm{h}$ and operated above 200 volts. The long life battery delivered the requested ten, 10-second pulses above 50 volts under a 4.2 KW constant power load. This system is presently being considered for further development.

\section{Mines}

Cadmium/mercuric oxide and zinc/mercuric oxide batteries are presently being used to power several navy mine systems. Both of these batteries contain heavy metals (cadmium, mercury) which are extremely toxic. This poses difficult issues of battery disposal and the uncertainty of long-term battery availability. Accordingly, the Navy is funding a program to qualify lithium/thionyl chloride cells in "6", " $\mathrm{C}$ " and "A" sizes as part of a larger program to standardize mine battery chemistries and cell sizes for mine applications.

Lithium/thionyl chloride was selected as the first "standard" electrochemistry because of its maturity, long shelf life, high energy density, low cost and good vendor availability.,4 However, this electrochemistry also presents potential problems since the liquid cathode, thionyl chloride, is highly toxic and corrosive. The Navy has recognized the need to evaluate alternative electrochemistries because of this issue and is therefore investigating solid cathodes. Lithium/carbon monofluoride appears to be ideally suited to mine battery operational requirements. It is thermally stable to $400^{\circ} \mathrm{C}$ and the discharge products, LiF and carbon, are inert and environmentally benign. The lithium/carbon monofluoride battery also has an attractive energy density (250-480 Wh/kg), a low self discharge rate $(0.5 \%$ per year) and is commercially available from several vendors. However, it is subject to voltage delay and has not found widespread use because it is relatively expensive.

A recent program, initiated by the Navy, is aimed at correcting these deficiencies. It will seek the preparation of new carbon-fluoride $\left(\mathrm{CF}_{\mathrm{x}}\right)$ cathode materials that will improve cell performance. Compounds such as those reported by the USSR Academy of Sciences and Angarsh Electrochemical Company will be investigated. Scientists there have claimed a novel $\mathrm{CF}_{1.18}$ to 1.33 compound operating between 3.0 and 3.5 volts and possessing a higher rate capability. The energy density of a Li/CF 1.33 battery would be 330-640 $\mathrm{Wh} / \mathrm{kg}, 33 \%$ higher than that of the conventional $\mathrm{Li} / \mathrm{CF}_{1.00}$ battery.

\section{Underwater Vehicles}

Unmanned Undersea Vehicles (UUV's) are capable of executing many missions (e.g. mine detection, mine neutralization, shallow water surveillance, decoy and disruption and covert mapping. These systems, as well as the manned Swimmer Delivery Vehicle (SDV), presently use silver oxide/zinc batteries. Several major disadvantages are associated with this battery. Although silver zinc is the most energetic high-rate secondary battery presently available, its energy density still limits its useful range. Other drawbacks include: (1) the limited number of charge-discharge cycles possible before failure, (2) a substantial drop in energy density near the end of cycle life, (3) a low wet stand life, and (4) a high, battery-related cost due to items (1) through (3). Future missions will require an energy source that can deliver at least twice the energy density of silver oxide/zinc under 
low drain rates. The battery must be affordable, environmentally benign and safe. Logistics would be simplified if batteries were capable of recharge on a surface platform or submarine host platform.

NSWC presently has four development efforts aimed at underwater vehicle propulsion. Two are directed toward developing new electrochemistries for the mid and far term, while the remainder are attempting to improve the mature silver oxide/zinc technology for the near term. The goals of these efforts are listed in Table 1 which shows projected increases in gravimetric energy and power densities versus $50 \mathrm{Wh} / \mathrm{lb}$ and $225 \mathrm{~W} / \mathrm{b}$ for silver oxide/zinc. swelling on initial charge. Alliant proposes to reinforce the walls by means of external bracing of cells within a tray of SDV modules. SAFT proposes strengthening cell cases by pinning two opposing faces together internally. To date, due to internal shorting by lithium dendrites, no more than 20 cycles has been achieved by either company.

Rayovac (Madison, WI) ${ }^{6}$ and Covalent Associates (Woburn, MA) have been developing the lithium ion technology. This technology system offers the promise of achieving a much longer cycle life in comparison to lithium metal. Under a contract awarded in 1992, Rayovac is investigating

Table 1. Goals of Rechargeable Battery Efforts in Relation to Present Silver Oxide/Zinc Technology

\begin{tabular}{|c|c|c|c|c|}
\hline Electrochemistry & Battery Design & $\begin{array}{c}\text { Energy Density } \\
\text { Increased By }\end{array}$ & $\begin{array}{c}\text { Power Density } \\
\text { Increased By }\end{array}$ & $\begin{array}{c}\text { Cycle Life } \\
\text { Increased By }\end{array}$ \\
\hline Lithium/Cobalt Oxide & monopolar & $100 \%$ & $0 \%$ & $100 \%$ \\
\hline Lithium Ion & monopolar & $0 \%$ & $0 \%$ & $500 \%$ \\
\hline Silver Oxide/Zinc & monopolar & $50 \%$ & $0 \%$ & $50 \%$ \\
\hline Silver Oxide Zinc & bipolar & $0 \%$ & $200-300 \%$ & $0 \%$ \\
\hline
\end{tabular}

Alliant Techsystems (Horsham, PA) and SAFT Research and Development Center (Cockeysville, MD) have parallel contracts with NSWC for the development of a 100 Ah size, lithium/lithium cobalt oxide cell. Prior development by Alliant had shown a significant benefit for underwater vehicle propulsion from switching from a rechargeable silver/zinc to a rechargeable lithium power supply. ${ }^{5}$ The $100 \mathrm{Ah}$ cell will provide the engineering baseline for the ultimate cell, or module of cells, that will form the 600 Ah unit required for propulsion by a Swimmer Delivery Vehicle (SDV). Both contractors have selected a prismatic design and will use a carbon dioxide $\left(\mathrm{CO}_{2}\right)$ doped, methyl formate electrolyte. The two, however, have significantly different approaches to compensate for the internal stresses caused by the $\mathrm{CO}_{2}$ pressure and plate high capacity anode materials using coin cells. During the second half of this effort, they will develop an 8 Ah prismatic cell. Under a recently awarded contract, Rayovac plans to bring the technology to the 100-150 Ah cell size by the end of FY97. Covalent is performing anode material development on the $\mathrm{Li}_{\mathrm{x}} \mathrm{C} / \mathrm{Li}_{\mathrm{x}} \mathrm{CoO}_{2}$ system under the Small Business Innovative Research Program. The first phase of Covalent's effort was performed in laboratory cells. Future efforts would seek the development of larger cells (20Ah).

Significant improvements to the silver/oxide zinc couple have been achieved in collaboration with Yardney Technical Products (Pawcatuck, CT) ${ }^{7,8}$ Employing a monopolar construction, cells containing a new class of materials, known as Electro-Permeable Membranes, yielded a $68 \%$ 
longer cycle life and a 38\% better utilization of the active materials compared with Yardney's standard cells, when cycled at the $\mathrm{C} / 3$ rate.. These materials are used as additives and/or coatings for the negative electrodes and as coatings for the separators. Work has also been initiated to increase the power capability of silver oxide/zinc. Yardney intends to achieve this objective by developing a bipolar electrode, in which both positive and negative electrode materials are built on a common current collector. Such construction should lead to over four times the power output per unit volume, compared to conventional (monopolar) batteries. The major obstacle to this development in the past has been intercell electrolyte leakage which causes self discharge due to parasitic currents.

\section{Torpedoes}

During the last 20 years, torpedo development has focussed on achieving greater speeds. However, considering the increasing efficiency of countermeasures, the quietness of new submarines, and an emphasis on cost, future torpedoes must also be smarter, stealthier, and affordable. The Naval Undersea Warfare Center, Newport, RI, has been developing the aluminum/silver oxide $(\mathrm{Al} / \mathrm{AgO})$ battery on and off since the seventies. It is a very high power system and can achieve discharge rates over $1 \mathrm{amp} / \mathrm{cm}^{2}$. The $\mathrm{Al} / \mathrm{AgO}$ battery is activated by the injection of seawater and alkali. During discharge, a flow of pumped electrolyte (seawater plus conducting salt) is required to remove discharge products and excess hydrogen and heat. The French and Italian MURENE lightweight torpedo also uses this technology which was developed at SAFT. Although this system is reported to have excellent energy densities $(73 \mathrm{Wh} / \mathrm{lb})^{9}$, there is concern about its cost; the aluminum alloy used in the $\mathrm{Al} / \mathrm{AgO}$ battery is very expensive. Development efforts at NUWC are now underway to provide a more affordable technology such as aluminum/hydrogen peroxide. $^{10}$

\section{References}

1. P. G. Russell and F. Goebel, Proceedings of the 36th Power Sources Conference, 6-9 June 1994, pp 376-379.

2. J. D. Briscoe, G. Castro, and J. Gessler, Proceedings of the 36th Power Sources Conference, 6-9 June 1994, pgs 408-410.

3. J. A. Banner, C. S. Winchester, and W. P. Kilroy, Proceedings of the 36th Power Sources Conference, 6-9 June 1994, pgs 17-172.

4. W. P. Kilroy, J. A. Banner, and F. Walsh, Proceedings of the 36th Power Sources Conference, 6-9 June 1994, pgs 358-360.

5. P. H. Smith, S. D. James, D. L. Chua, H-P. W. Lin, and C. W. Fleischmann, Power Sources, vol. 14, Edited by A. Attewell and T. Keily, pgs 257-265 (1993).

6. W. Ebner, D. Fouchard, L. Xie, S. Megahed, Proceedings of the 36th Power Sources Conference, 6-9 June 1994, pgs 65-68.

7. R. Serenyi, Naval Surface Warfare Center, Dahlgren Division Technical Report 92/296, S.D. James, editor, 3 March 1994.

8.. R. Serenyi, Proceedings of the 36th Power Sources Conference, 6-9 June 1994, pgs 278-281.

9. Naval Forces, No, 1, vol, XV (1994).

10. C. L. Marsh, Editor, Proceedings of the Aluminum-Hydrogen Peroxide Battery Technology Workshop, Naval Undersea Warfare Center Technical Document 10,052, 1 May 1992. 